The Sri Lanka Journal of the Humanities (2018) 42: 1-2, 01-28

DOI: http://doi.org/10.4038/sljh.v42i1-2.7253

Published online: 28 November 2019

(c) (i)

(C) University of Peradeniya

\title{
The Education of Buddhist Monks in Sri Lanka: A Historical Review and Some Suggestions for Reform ${ }^{1}$
}

\author{
CHANDRA R. DE SILVA ${ }^{1}$ \\ ${ }^{1}$ Old Dominion University, USA \\ ${ }^{1}$ cdesilva@odu.edu \\ 1 (iD) https://orcid.org/0000-0002-2906-4601
}

\begin{abstract}
The education of Buddhist monks had traditionally been a matter of studying under renowned scholar-monks. However, during colonial times there was a gradual replacement of monasteries as centers of training of monks by new piriven educational institutions. These institutions gradually became widespread in the nineteenth and twentieth centuries as the colonial state worked with Buddhist
\end{abstract}

\footnotetext{
${ }^{1}$ Some ideas contained in this chapter were presented at the Annual Meeting of the South-Eastern Conference of the Association for Asian Studies, Tallahassee, FL January 12-13, 2001. Others were expressed in the blog SouthAsia @LSE, see http://blogs.lse.ac.uk/southasia/2018/03/26/why-we-need-to-reform-the-education-ofbuddhist-monks-in-sri-lanka/. Tilak Jayatillke, Ananda E. de Silva and Vishwamiththra Senadeera were of assistance in the procurement of history texts used in piriven.
} 
leaders to establish a centrally designed curriculum and formal examinations. At the same time, the growth of the nationalist movement among Sinhalese Buddhists gave new legitimacy to the understanding of Lanka's history as a journey from SinhalaBuddhist origins. This article traces the many efforts to reform the piriven and their curricula. Through an analysis of the history textbooks used at the first level of piriven education in the late $20^{\text {th }}$ and early $21^{\text {st }}$ centuries, this article concludes that the education given to novice Buddhist monks downplays the contribution of ethnic and religious minorities to Sri Lanka's history. It is argued that the development of a more inclusive history curriculum for the education of monks, together with other factors such as better teacher training, would enable Buddhist monks to play a more effective role in the diverse country that Sri Lanka has come to be today.

Keywords: education, curriculum, nationalism, inclusion, colonial impact

We often assume that the global spread of modern systems of education can only lead to increased knowledge, greater critical skills and, perhaps even more tolerance and understanding. I use the case of the transformation of a system used to educate Buddhist monks in Sri Lanka to suggest that a modern education system is a two-edged sword. I also contend that changes introduced (in this case changes introduced by a Westernizing colonial power and continued by an independent postcolonial state) could (and in this particular case, did) lead to unanticipated, and in some respects, adverse consequences.

I write a decade after the end of a civil war in Sri Lanka, a war that lasted for almost three decades and cost many thousands of lives. ${ }^{2}$

\footnotetext{
2 The literature on the conflict is extensive. For slightly different interpretations of the origins of the conflict see, Wilson, A. Jeyaratnam. Sri Lankan Tamil Nationalism: Its Origins and Development in the $19^{\text {th }}$ and $20^{\text {th }}$ Centuries. London: C. Hurst, 2000 and de Silva, K. M. Managing Ethnic Tensions in Multi-ethnic Societies: Sri Lanka 1880-1985. Lanham: University Press of America, 1986. K. M. de Silva's Sri Lanka and the Defeat of the LTTE. Colombo: Vijitha Yapa, 2012 provides a readable account of the course of the civil war.
} 
We also live in a context where the many Buddhist monks in Sri Lanka are perceived, rightly or wrongly, as adopting a hard line against the demands for autonomy by the Tamil nationalist groups and less than tolerant of other religious groups. ${ }^{3}$ I agree with the view that many in the sangha have a world-view that has romanticized a mythical, ideal past in which Sri Lanka was a 'Sinhalese-Buddhist country'4 and that this view is supplemented by a perception of threats (from the Christian West, as well as from non-Buddhist minorities, particularly Tamils). Such a view, together with recent ethnic conflicts, has made many Buddhist monks skeptical of a decentralized polity and hostile to ethnic and religious minorities in Sri Lanka. ${ }^{5}$ In this essay, I seek an explanation for the dominance of this world-view among Buddhist monks. To do so, I assume that, while the political culture of a group is fashioned by a variety of influences including the media, much of the information we receive is often processed and analyzed through

\footnotetext{
${ }^{3}$ See, de Silva, Chandra R and Tessa Bartholomeusz. The Sangha and the Reconciliation Process in Sri Lanka. Colombo: Marga Institute, 2001 and de Silva, Chandra R. "Buddhist Monks and Peace in Sri Lanka." Buddhism, Conflict and Violence in Modern Sri Lanka, ed. Mahinda Deegalle, New York: Routledge, 2006, pp. 202-209. For examples of differing attitudes among contemporary monks see de Silva, Chandra R. "The Plurality of Buddhist Fundamentalism: An Inquiry into Views Among Buddhist Monks in Sri Lanka." In Buddhist Fundamentalism and Minority Identities in Sri Lanka, edited by Tessa Bartholomeusz and Chandra R. de Silva, Albany: State University of New York Press, 1998, pp. 53-73.

${ }^{4}$ The Mahanayake of Kotte Chapter the Most Ven. Ittepane Darmalankara Thera stated in May 2019, "During the history that I know of, no Buddhist or any nonBuddhist had ever said that Sri Lanka is not a Sinhala Buddhist country.. . . In this backdrop, if anyone says that Sri Lanka is not a country of Sinhala Buddhists, such people are not fit to be in the country." See http://www.dailymirror.lk/breaking_news/Those-say-SL-not-a-Sinhala-country-notfit-to-be-in-it:-Darmalankara-Thera/108-167029 Accessed July 17, 2019.

${ }^{5}$ The opposition of prominent Buddhist monks to the idea of a federal state compelled the Sri Lankan government in power to proclaim in 2018 that the constitution being proposed would be unitary in nature. On June 15, 2019, some two months after the Muslim terrorist attacks on hotels and churches in Sri Lanka, the Chief Prelate of the Asigiri Chapter of the Siyam Nikaya, Ven. Warakagoda Sri Gnanarathana called for a boycott of Muslim-owned shops. https://www.youtube.com/watch?time_continue=61\&v=P7AVLSm2I_A Accessed July 18, 2019.
} 
conceptual frameworks which are developed early in life. Therefore, education systems and curricular content and designs in the early stages of education are crucial in fashioning attitudes which often have a lifelong impact. ${ }^{6}$

In what ways did the education system for Buddhist monks change in the nineteenth and twentieth centuries? My contention is that there were two crucial modifications. The first of these involved changes in the curriculum accompanied by a new uniformity in the structure of education, influenced, if not imposed by, state mandates and regulations. These changes were introduced in the early twentieth century by a centralizing colonial state influenced by Orientalist perceptions, and as mentioned before, they were continued by the newly independent state in Sri Lanka in the second half of that century. Educational levels began to be measured through success at standardized examinations. Further changes in the late twentieth century made the validation of the monastic education system become increasingly dependent on attaining equivalence with the new secular examinations. These curricular and organizational changes became even more significant because of reevaluations of their own role by monks, re-evaluations that began from at least the seventeenth century, but became crucial in the nineteenth and twentieth centuries. ${ }^{7}$ The second change relates to an alteration in the criteria for the validation of education of monks. We see that the earlier justification for monks' education, which was the furtherance of their religious mission, became gradually overshadowed by their role in preserving the national heritage (which, to colonial elites, was the fostering of 'Oriental' learning).

Let us first reflect briefly on the old Buddhist institutions of learning that developed in Sri Lanka. Institutions for the education of

\footnotetext{
${ }^{6}$ For a broader survey on the relationship between education and violence in Sri Lanka see, de Silva, Chandra R. "The Role of Education in Ameliorating Political Violence in Sri Lanka." Creating Peace in Sri Lanka: Civil War and Reconciliation. edited by Robert I. Rothberg, World Peace Foundation, 1999, pp. 109-129.

${ }^{7}$ For a discussion of some of these re-evaluations see Seneviratne, H. L. The Work of Kings: The New Buddhism in Sri Lanka. Chicago: University of Chicago Press, 1999 and de Silva and Bartholameusz. The Sangha and the Reconciliation Process. pp. 412 .
} 
Buddhist monks had existed from very early times. We find references to Buddhist educational institutions in Nalanda, Taxila and other centers in India in pre-Christian times. In Sri Lanka, centers of learning grew up in the major monastic centers such as the Mahavihara, Thuparamaya and Chetiya vihara. In time, there grew to be many centers of learning. All of them were autonomous educational institutions, but, from at least the seventh century of the Christian era to about the $15^{\text {th }}$ century, each center belonged to one or the other of a number of scholarly traditions that were established through key institutions (mulāyatana). ${ }^{8}$

Evidence gleaned indirectly from chronicles and other sources indicate that, during this period, the curricular content of monastic education underwent changes. Thus, for example, by the fourteenth century, Tamil language was added to Sinhala, Pali and Sanskrit as a subject studied in several educational institutions for monks. ${ }^{9}$ However, the primary purpose of monastic education remained the training of monks both for their own spiritual development and to enable them to provide a better service to lay persons. The organization of learning changed too. By the fifteenth century, the term pirivena (pl. piriven), originally used to denote a cell or residence for a monk, ${ }^{10}$ had begun to refer to a specialized institution of learning. Piriven had lands donated to them so that they became autonomous institutions in terms of their maintenance. However, the education of monks was still a matter of studying under renowned scholar-monks. Furthermore, apart from occasionally honoring learned monks and providing the piriven with grants of land, the state and other secular organizations had little to do with the education of monks.

\footnotetext{
${ }^{8}$ Adhikari, Abhayaratna. Sri Lankāvē Sambhāvya Adhyāpanaya hā Mahasañgana. Colombo: S. Godage and Sons, 1991, pp.11-38, 57-72; Ilangasinha, Mangala.

"Piriven Adhyāpanaya: Itihāsaya, Aramuṇu hā Navīkaraṇaya." Sambhāṣā 14, 2006, pp. 212-234.

${ }^{9}$ Girā Sandeśaya, edited by Munidasa Kumaratunga, Colombo: 1955, stanza 227.

${ }^{10}$ Rahula, Walpola. History of Buddhism in Ceylon: The Anuradhapura Period, $3^{\text {rd }}$ Century BC-10th Century AC. Colombo: Gunasena, 1956, p. 132; Ilangasinha, Mangala. Buddhism in Medieval Sri Lanka. Delhi: Sri Satguru Publications, 1992, pp. 133-135; Adhikari, Abhayaratna. "1947, 1959 Piriven Vyavasthā, 1964 An̉ka 64 Daraṇa Piriven Adhyāpana Panata Hā Niyōga Mālā.” Sambhāṣā, 14, 2006, pp. 194 195.
} 
Indications from the fifteenth and sixteenth centuries suggest that piriven had some commonalities. Ilangasinha, who has made a comprehensive study of the sources for this period argues that piriven probably had lay students as well as monks. ${ }^{11}$ All novice monks clearly studied the texts on discipline (vinaya) and elements of grammar. ${ }^{12}$ After ordination, monks proceeded to study the abhidhamma and finally, each monk specialized in one area of Buddhist doctrine. However, much of the emphasis in the training of monks seems to have been on disciplinary rules and preaching. ${ }^{13}$

On the other hand, a comparison of two of the major piriven show significant differences in the subjects taught. Ilangasinha points out "while the Padmavati Pirivena forbade its students to study politics (arthasastra), students of the Vijayabāhu Pirivena were taught that subject." ${ }^{14}$ The study of other religions seems to have been valued more in the Vijayabāhu Piriveṇa than in the Padmāvatī and this might have led to the development of some elements of religious syncretism in the former. ${ }^{15}$ Thus, piriven were autonomous institutions with some diversity in respect of the curriculum.

The piriven that reemerged after a period of disruption due to the impact of the Portuguese colonial incursion were reborn in a different context. ${ }^{16}$ After a long period of Dutch rule in the lowlands, the British

\footnotetext{
${ }^{11}$ Ilangasinha, Mangala. Buddhism. p. 142. The Girā Sandeśaya stanzas 219-230 on the Vijayaba Pirivena at Totagamuva mentions lay students and monks in contrast to the Hamsa Sandeśaya edited by C. E. Godakumbura, Colombo: 1953, stanzas 169-173 which mentions only monks as students at the Padmavati Pirivena at Karagala.

${ }^{12}$ Hamsa Sandeśaya. stanza 109; Girā Sandeśaya. stanza 222.

${ }^{13}$ Haṃsa Sandeśaya. stanza 174-176; Girā Sandeśaya. stanza 229. Monks were also taught languages including Sanskrit, Pali and Tamil. See Ilangasinha, Mangala. Buddhism. pp. 147-148; Mirando, A. H. Buddhism in the $17^{\text {th }}$ and $18^{\text {th }}$ Centuries with Special Reference to Sinhalese Literary Sources. Dehiwala: Tisara Prakasakayo, 1985, p. 10.

${ }^{14}$ Ilangasinghe, Mangala. Buddhism. p. 150

${ }^{15}$ Mirando, A. H. pp. 8-19

${ }^{16}$ Anne Blackburn correctly points out that between the end of the seventeenth century and the nineteenth century, there were no piriven where monks from different monasteries congregated for training. Monastic learning took place largely
} 
had taken over and conquered the inland kingdom of Kandy. ${ }^{17}$ Colonial rule had given Christianity (Roman Catholicism under the Portuguese, Calvinism under the Dutch and the Anglican Church under the British) distinct advantages. ${ }^{18}$ Indeed, although the revival of Buddhist learning in the Kandyan kingdom in the late eighteenth century had some impact on the lowlands under colonial rule, Buddhist monks saw both their religion and Sinhala culture pushed into the periphery by the triumph of colonialism. ${ }^{19}$ Christian missionaries, backed by Western powers ruling in the coastal areas constantly derided Buddhism as "superstition." ${ }^{20}$ This changed context is why the Niyamakanda Sämañera Pirivena, which emerged in the 1730s, was seen as an agency for scholarly production rather than as an institution that promoted discipline and training of monks. ${ }^{21}$ Nevertheless, for much of the eighteenth and nineteenth centuries, there was a great deal of continuity in terms of the education and training of monks because most instruction continued to be within individual monasteries (not in specialized piriven), and disciplinary texts and training in preaching and the chanting of pirit took up much of the time in the early stages of education. ${ }^{22}$ After 1753 ,

in individual monasteries. Blackburn, Ann M. Buddhist Learning and Textual Practice in Eighteenth Century Lankan Monastic Culture. Princeton: Princeton University Press, 2001, p. 44.

${ }^{17}$ For details see, University of Peradeniya. History of Sri Lanka, Vol. II edited by K. M. de Silva, Peradeniya: University of Peradeniya, 1995.

${ }^{18}$ See, Jayasuriya, J. E. Educational Policies and Progress During British Rule in Ceylon (Sri Lanka) 1796-1948. Colombo: Associated Educational Publishers, 197?, pp. $57 \mathrm{ff}$.

${ }^{19}$ Hewawasam, P. B. J. Mātara Yugayē Sāhityadharayan hā Sāhitya Nibandhana. Colombo: Ministry of Cultural Affairs, 1966.

${ }^{20}$ For almost a century, Roman Catholic missionaries found refuge from Dutch Calvinist persecution in the Kandyan kingdom. See Dewaraja, L. S. "Religion and the State in the Kandyan Kingdom: The $17^{\text {th }}$ and $18^{\text {th }}$ Centuries." University of Peradeniya, History of Sri Lanka, Vol. II, edited by K. M. de Silva. pp. 468-469 and for the $19^{\text {th }}$ century see, J. E. Jayasuriya, Educational Policies. pp. $77 \mathrm{ff}$ ${ }^{21}$ Blackburn, Ann M. Buddhist Learning. pp. 49-50,116-125.

${ }^{22}$ Sañgharāja Sādhucariyāva, edited by N. Pannasena and P. B. Sannasgala, Colombo: 1947, pp. 5, 9; Adhikari, Abhayaratna. Śrī Laṃkave Sambhāvya Adhyāpanaya. pp. 241-247; Ruberu, Ranjith. Education in Colonial Ceylon. Kandy, 1962, p. 241 states that 94 Buddhist schools were reported to the Colebrooke Commission but also states 'Probably the Buddhist schools were really classes 
successors to Niyamakanda, called madyasthāna and vidyāsthāna, spread in Kandyan areas and in the southwest under Dutch rule. However, despite Hewawasam's contention that these institutions in the southwest provided higher education, it is likely that only a minority of monks were educated beyond the instruction they received in their own temples. ${ }^{23}$ There were no formal examinations. ${ }^{24}$ Nevertheless, there had now developed "for the first time since the early sixteenth century- a centralized education system that trained monks within a common curriculum." ${ }^{25}$

A change that I wish to concentrate on began in the late $19^{\text {th }}$ century, and continued through the $20^{\text {th }}$. Emblematic of this change is the gradual replacement of monasteries as centers of bhikkhu training by new piriven educational institutions. These piriven, though often located within monastic premises, became gradually recognized as distinct from them. The beginnings of this process can be traced to the emergence of a pirivena in Pelmadulla under Ven. Galle Medhankara in the early part of the nineteenth century.

Some decades later, in 1858, Walane Sri Siddhartha established a similar institution in Ratmalana. Other piriven were founded in Bentara, Payagala and Panadura before Hikkaduwe Sri Sumangala set up the Vidyōdaya Pirivena at Maligakanda in 1873 and Ratmalane Sri Dhammaloka established the Vidyālankkāra Pirivena at Paliyagoda in 1875. The expansion was slow but steady. By 1917 there were 62 piriven. By the end of British rule in 1948, there were 129 such institutions with

\footnotetext{
conducted by Buddhist priests in their temples.' It is likely that this represented significant under-reporting. The first official count of temple schools made in the Ceylon Sessional Paper in 1897 entitled 'An Account of the System of Education Existing in Ceylon' reported 1516 temple schools. See Wickremaratne, Ananda. The Roots of Nationalism: Sri Lanka. Colombo: Karunaratna \& Sons, 1995?, p. 106.

${ }^{23}$ Blackburn, Ann M. Buddhist Learning. p. 53; Hewawasam, P. B. J. Mātara Yugaye. pp.16-17.

${ }^{24}$ Blackburn, Ann M. Buddhist Learning. p. 59.

${ }^{25}$ Blackburn, Ann M. Buddhist Learning. pp. 59-75.
} 
3,768 students and 372 instructors. ${ }^{26}$ This growth of piriven from the late $19^{\text {th }}$ century onwards occurred in an era during which four currents became intertwined with fateful results.

The first of these currents was what K. N. O. Dharmadasa calls a rise of Sinhala 'language loyalty.' Influenced by the exclusion of locals from political power as well as the denigration of Sinhala by some British officials and influenced by the writings of European philologists, Sinhala scholars like James d'Alwis began a vigorous defense of the Sinhala language and culture. ${ }^{27}$ The second includes the 'revival' of Buddhism fueled by controversies and debates (especially debates with Christian missionaries 1864-1873 ${ }^{28}$ ), the growth of Sinhala language journals, ${ }^{29}$ and eventually, in the early years of the new century, by the use of Sinhala novels and the theater to promote a Sinhala Buddhist identity. ${ }^{30}$ The third current was the privileging of a certain vision of Lanka's past, fostered by a growing interest in historical sources by Western Orientalist scholars and the educated elite in Sri Lanka. The major Sinhala Buddhist chronicle, the Mahãvamsa was published in English translation as early as the $1830 \mathrm{~s} .{ }^{31}$ The Ceylon Branch of the Royal Asiatic Society was set up in 1845 . By 1890, the British colonial government established a Department of Archeology to preserve and

${ }^{26}$ Adhikari, Abhayaratna. Śrī Lamkāve. pp. 256, 300-301; Dharmadasa, K. N. O. Language, Religion and Ethnic Assertiveness: The Growth of Sinhalese Nationalism in Sri Lanka. Ann Arbor: University of Michigan Press, 1992, p. 111.

${ }^{27}$ Dharmadasa, K. N. O. Language, Religion and Ethnic Assertiveness. pp. 27-85.

${ }^{28}$ Dharmadasa, K. N. O. Language, Religion and Ethnic Assertiveness. pp. 89-103. ${ }^{29}$ The first Buddhist newspaper in Sinhala, the Lakminipahana (established in 1862) had a brief existence in the 1860s and was followed by the Satya Mārgaya (1867- early 1870s). More influential was the Sarasavi Sandaræsa set up in 1880. See, Wickremeratne, Ananda. The Roots of Nationalism: Sri Lanka. pp. 31, 277-278 and Dharmadasa, K. N. O. Language, Religion and Ethnic Assertiveness. pp. 117125.

${ }^{30}$ Dharmadasa, K. N. O. Language, Religion and Ethnic Assertiveness. pp. 126-129. ${ }^{31}$ Mahāvamso, edited by George Turnour, Cotta: Ceylon Mission Press, 1837. There was an earlier translation of the Mahāvamsa published in 1833 as The Mahavamsi, the Rajaratnacari and the Raja-Vali Forming the Sacred and Historical Books of Ceylon. edited by Edward Upham, London: Parbury Allen, 1833, but it had some errors. See, Kemper, Steven. The Presence of the Past: Chronicles, Politics and Culture in Sinhala Life. Ithaca: Cornell University Press, 1991, pp. 86-87. 
study ancient cities. The understanding of Lanka's history as a journey from Sinhala origins began to receive a new legitimacy. Finally, changes in education policy in England gave birth to the idea that the colonial state was responsible for the spread of education. The British colonial government had, almost from the outset, supported Christian missionary organizations that used primary education as a means of conversion. ${ }^{32}$ In 1869 , as a result of recommendation of a special committee of the Legislative Council, the government set up a Department of Public Instruction under a Director and accepted the idea that the state would work with religious organizations to further public education. ${ }^{33}$ From 1870, the colonial state began to aid (Christian) religious organizations with state funds. This marked a new stage of a process whereby schools gradually came under state control and supervision. ${ }^{34}$

The intertwining of these four currents contributed to the further identification of Buddhism with Sinhala culture and a confluence of interest in Sinhala Buddhist culture and heritage among the Western (and Westernized) Orientalists, the colonial state and leaders of monks. A good example of this coming together can be seen in the publication of a Sinhala translation of the Mahãvamsa in $1877 .{ }^{35}$ Here was a Buddhist monk who headed a pirivena, working with a Sinhala scholar to translate the chronicle and the publication of the translation was encouraged by Sir William Gregory, the British Governor of the colony (1872-1877) and was financed with state funds. ${ }^{36}$

\footnotetext{
${ }^{32}$ Jayasekera, P. V. J. Confrontations with Colonialism: Resistance, Revivalism and Reform under British Rule in Colonial Sri Lanka, 1796-1920, Vol. I. Colombo: Vijitha Yapa, 2017, pp. 235-246.

${ }^{33}$ Jayasuriya, J. E. Educational Policies. pp. 204-217, 233-234.

${ }^{34}$ Jayasuriya, J. E. Educational Policies. pp. 256-275.

${ }^{35}$ Mahāvaṃsa, translated by Sumangala, Hikkaduwe and Pandit Batuvantudawe. Colombo: Government Press, 1877. Before 1877, the Mahãvamsa was available only in its original Pali verse text and (since the 1830s) in English translation. However, stories from the Mahāvamsa seem to have been known in Sri Lanka probably through sermons of Buddhist monks who read the Pali text.

${ }^{36}$ For a good analysis of how the monk, Hikkaduwe Sri Sumangala and Pandit Batuvantudawe achieved their own objectives while being in partnership with the British Governor, see Blackburn, Anne M. Locations of Buddhism: Colonialism and
} 
Of course, the groups that thus came together for this project had different motives. From the point of view of the Orientalists, the task of fostering and preserving knowledge of traditional Pali, Sanskrit and Sinhala literature, was perhaps more important than the education of Buddhist monks, although obviously, the two were linked. British Government, sponsorship of the project was partly based on hopes for the enhancement of popular support for their rule but the British also had other motives. While the piriven were as yet few in number, in 1888 the government recorded the existence of 1769 temple schools for lay children. British officials were not impressed with these temple schools. On the contrary, they saw them as places where students received an unproductive education, memorizing works in Pali, a language that they did not understand. They were concerned about how to broaden the education given in such schools and, clearly, one way to do this was to stimulate changes in the education given in the piriven. From the point of view of many monks and educated lay Buddhists, state patronage was welcome as a symbol of the resumption of state interest in the welfare of the religion of the majority of the people. ${ }^{37}$ However, their interest was in developing educational institutions that not only trained monks but also fostered learning in areas such as astrology, traditional medicine, and history. ${ }^{38}$ All these perceptions contributed to support for a change in piriven education.

It is the concrete results of the change that should interest us. The first of these relates to changes in the curriculum. In 1878, within a few years of the establishment of the Vidyōdaya Pirivena, the British colonial government inaugurated an annual grant of Rs. 600 in support of the institution. However, British education officials expressed disappointment that geography and arithmetic were not in the curriculum. The very next year, arithmetic was included and a few years

Modernity in Sri Lanka. Colombo, Social Scientists Association, 2010, pp. 70-78. For a questioning of the idea of local agency in colonial times see, Abeysekera, Ananda. "Protestant Buddhism and "Influence": The Temporality of a Concept." Qui Parle, Vol. 28 (1), June 2019, pp. 1-75, esp. pp. 22-27.

${ }^{37}$ Dharmadasa, K. N. O. Language, Religion and Ethnic Assertiveness. p.180.

${ }^{38}$ Blackburn, Ann M. Locations. pp. 40-45. 
later the annual grant was increased to Rs. 1,000 a year. ${ }^{39}$ This, in itself, was fairly innocuous, but with state grants there came state monitoring and the establishment of a regular system of examinations. Examinations were present in the Vidyōdaya Piriveña before the advent of state aid but such examinations appear to have been mostly oral although there is reference to 'examination papers' in an 1875 account. ${ }^{40}$ Substantial change came later. In 1902 Education Director S. M. Burrows summoned a meeting to discuss ways to assist and foster oriental learning. The Committee of Oriental Studies that he summoned on July 24, 1902 consisted of 23 persons including himself, six Buddhist monks, two Christian priests, five editors of Sinhala newspapers, the Government's Interpreter Mudaliyar and seven other lay scholars. This committee eventually developed into the Prācīna Bhāsōpakāra Samāgama (PBS or the Association for the Fostering of Oriental Languages). The first Executive Committee of the newly formed PBS included the new Education Director J. Harvard, Interpreter Mudaliyar W. F. Gunawardhana, Ven. Hikkaduwe Sri Sumangala, Ven. Ratmalane Sri Dharmarama, Ven. Waskaduwe Sri Subhuthi, Dr. D. B. Jayatilleke and a lawyer, W. P. Ranasinha. Given this distinguished leadership it was possible for PBS to win wide acceptance among the sangha. The main activity of the PBS was to systematize and conduct examinations.

After 1903, through its prācīna examinations (Preliminary, Intermediate and Final), the PBS began to have a crucial impact on the curriculum of the piriven. By 1910, the chief subjects for the prācina examinations included such new subjects as the history and archeology of Sri Lanka, Pali, and inscriptional Sinhala. ${ }^{41}$ Many scholars have seen the work of the PBS in a very positive light. Dharmadasa for instance pointed out that "Apart from the systematization and coordination of pirivena education, which the committee was able to accomplish, its very

\footnotetext{
${ }^{39}$ Blackburn, Ann M. Locations. pp. 54-57: Jayasuriya, J. E. Educational Policies. p. 228. This amount was raised to Rs. 2,000 in 1919. See Adhikari, Abhayaratna. Śr $\bar{\imath}$ Lamkā̄ve. pp. 267-268.

${ }^{40}$ Blackburn, Locations, op. cit. p. 49.

${ }^{41}$ Adhikari, Abhayaratna. Śrī Laṃkāve. pp. 260-263; Blackburn, Ann M. Locations. pp. 51-52.
} 
establishment seemed to provide a much-needed imprimatur to the scholarly activities of the Buddhist literati." ${ }^{42}$

Ann Blackburn argues strongly that the Vidyōdaya Pirivena under Hikkaduwe Sri Sumangala resisted pressure from the colonial state to train teachers and to teach mathematics instead of arithmetic. ${ }^{43}$ However, change did seep in. It is true that historical writing had long been conducted in Buddhist monasteries. Now, for the first time, learning about Sri Lankan history and archeology had become an integral part of the higher training of all monks, and this came at a time when the history of Sri Lanka was being reinterpreted in nationalist terms. Thus, Anagarika Dharmapala could assert in 1903 "The island of Lanka belongs to the Buddhist Sinhalese. For 2455 years this was the land of birth for the Sinhalese. Other races have come here to pursue their commercial activities. For the Europeans, apart from this land, there is Canada, Australia, South Africa, England and America to go; for the Tamils there is South India, for the Moors. . Egypt; the Dutch can go to Holland. But for the Sinhalese there is only this island." 44 Piriven began to be the centers through which Buddhist monks received a view of their past, which validated the idea that Sri Lanka was a Sinhala Buddhist country. This idea was reinforced by theories that emerged around this time, theories of the Aryan descent of the Sinhala as compared with the Dravidian origin of the Tamils. ${ }^{45}$ The history syllabus used in the piriven seems to have reflected the view that the Sinhala Buddhist civilization was destroyed by South Indian (Tamil) invasions. ${ }^{46}$ Of course, there were other changes. Geography, Psychology and

\footnotetext{
${ }^{42}$ Dharmadasa, K. N. O. Language, Religion and Ethnic Assertiveness. p. 186. Ilangasinghe, H. B. M. "Piriven Adhyapanaya." p. 232 is more critical.

${ }^{43}$ Blackburn, Anne E. Locations. pp. 57-68.

${ }^{44}$ Sinhala Bauddhaya, January 20, 1912 quoted in Dharmadasa, K. N. O. Language, Religion and Ethnic Assertiveness.p. 186.

${ }^{45}$ Gunawardana, R. A. L. H. "The People of the Lion: The Sinhala Identity and Ideology in History and Historiography." The Sri Lanka Journal of the Humanities, Vol. V (1\&2) 1979, pp. 1-36.

${ }^{46}$ Thus, for example, the syllabus for history in the first year of a mülika pirivena in 1947 included topics such as The Aryans, Hinayana Buddhism, Hinduism, Agriculture and Irrigation, Foreign Trade, Relations with North India and South Indian Invasions.
} 
Hygiene were introduced into the curriculum. Tamil was made an optional subject in 1946, Hindi in 1949 and English and Arithmetic in 1954. Further changes in the curriculum were about to take place and to understand what they were, we need to investigate the second main consequence of the changes that arose with the activities of the PBS.

In brief, this change was that the basis of legitimacy for recognition of scholarly learning among monks began to move from the hands of individual scholar-monks into secular bodies like the PBS, and finally, into state hands. In fact, in 1945, the state Education Department took over the conduct of prācinna examinations. Detailed regulations were enacted about library and other facilities that were required and the records that had to be maintained. By 1947 it was decreed that piriven that received state aid had to obtain the permission of the Director of Education if they wished to appoint as instructors anyone who had not completed prācinna qualifications. As an indirect consequence of increased state power, qualifications obtained by monks began to be valued as much for their equivalence to secular examinations as for their own value. This process began as early as 1906 when it was decided that those who had completed the Prācina Madhyama Examination were exempt from the Sinhala Examination for notaries. $^{47}$

By the middle of the century, some piriven were preparing students for the Senior School Certificate Examination, which was the public examination that was held at the end of Junior Secondary schooling. Somewhat later, in 1959, W. Dahanayaka, Education Minister of independent Sri Lanka appointed 135 persons with who had successfully completed the Prācina Paṇdita Examinations as instructors to piriven institutions with salaries equal to those of university graduates. Indeed, a series of other changes made by Minister Dahanayaka in 1958-59 had a great impact on pirivena education.

The piriven were reclassified from a two-layered Mūlika (Basic) and Uparima (Advanced) into a three-layered Kaniștha (Junior), Jyẹstha (Senior) and Viśvavidyālaȳya (University). These piriven were allowed

${ }^{47}$ Adhikari, Abhayaratna. Śrī Laṃkāve. pp. 261. 
to present their students for secular national examinations conducted by the state Department of Examinations, viz. General Certificate of Education (Ordinary Level) and General Certificate of Education (Advanced Level). They were also allowed to teach students for university examinations if accredited to do so by any university. ${ }^{48}$ This was at the very time when the medium of education at the university level was being changed from English into Sinhala and Tamil and thus, thousands of lay students flocked into piriven to obtain a chance to gain admission to universities by performing well in these examinations. This is why enrollment in piriven tripled within a decade of 1958. By 1968 there were over 24,000 students enrolled in piriven. ${ }^{49}$ Lay students had been part of piriven education from the time we have data for such institutions, but in the 1960s, piriven became institutions in which close to (and, in some instances, more than) a majority of students were laymen. A few of the piriven became affiliated institutions of the new Vidyōdaya and Vidyālankkāra Universities (established in 1958) and prepared students for university examinations. The impact of these developments on traditional areas of study in piriven such as Pali and Sanskrit was disastrous. The number of students appearing for Prācīna Examinations through piriven declined. ${ }^{50}$ Piriven schools became simply poorer and less well-equipped versions of state schools, and their main task became preparing students for state run secular examinations. The only institutions that had traditionally provided an education for Buddhist monks had developed new priorities.

There was much concern in the 1970s about piriven education. Many claimed that the changes of the 50s and 60s which allowed piriven to present students for secular national examinations had harmed the training of Buddhist monks by diluting it through the introduction of subjects such as commerce into the curricula of piriven institutions. They argued that piriven education should be confined to the traditional

\footnotetext{
${ }^{48}$ See Section 13(1) of the regulations enacted by the Minister of Education on July $31,1959$.

${ }^{49}$ For statistics on the number of piriven, teachers and students from 1947 to 1968 see Jothipala, Gonahene. "Piriven Adhyāpanayē Siyavasaka Maga Salakunu." Sambhāṣā, 14, 2006, pp. 255, 259.

${ }^{50}$ At the same time, interest in Pali and Sanskrit in universities also fell sharply.
} 
languages, grammar, religious texts, preaching, with the possible addition of English. Others contended that the scope of piriven education should be expanded to include the sciences so that Buddhist monks would be able to respond knowledgeably to educated Buddhists. The government eventually appointed a special committee on piriven education whose report was published in 1971. The Pirivena Education Act of 1979 and the regulations promulgated under this act in 1980 included many of the recommendations of this Committee. ${ }^{51}$

The structure of piriven education thus established is that which still prevails in Sri Lanka. All piriven are classified into mülika, maha, and vidyāyatana piriven..$^{52}$ However, all three levels of piriven organized under a single management, might be present in one location. Jeffrey Samuels has correctly pointed out that the education of a monk depends not only on classes in the pirivena and the nightly advisory meetings with the preceptor but also the bonds each monk makes with other monks and the laity. ${ }^{53}$ Nevertheless, I contend that what monks imbibe in the formal classroom, especially in the early years, is likely to have a formative impact.

At the lowest level are the $467 m u \overline{l i k a}$ (primary) piriven ${ }^{54}$ that educate students through grade five. The mūlika piriven are five-year residential institutions aimed at training monks with an emphasis on discipline. Each male who enters a mülika pirivena is admitted to grade one, irrespective of age, to enable him to start learning Sanskrit and Pali from the beginning. Other required courses include Buddhist Scripture

\footnotetext{
${ }^{51}$ Wijayananda, Kaligama. Piriven Adhyāpanaya Hevat Sambhāvya Dēśìa Adhyāpanaya. Colombo: S. Godage, 2003, pp. 288-290; Pannasekera, Hureekaduwe. "Piriven Adhyāpanayē Aramuṇa hā Paramārtha." Guru Mæňdura III, Padukka: Shata Sanvathsara Uthsava Sanvardhana Kamituwa, 2010, pp. 141-149; Adhikari, Abhayaratna. “1947, 1959 Piriven Vyavasthā.” pp. 204-207.

${ }^{52}$ See Gazette (Extraordinary) of the Democratic Socialist Republic of Sri Lanka, No. 108/6, October 1, 1980.

${ }^{53}$ Samuels, Jeffrey. Attracting the Heart: Social Relations and the Aesthetics of Emotion in Sri Lankan Monastic Culture. Honolulu: University of Hawaii Press, 2010, p. 64.

${ }^{54}$ The figures are for 2017 (the latest available). See, http://www.statistics.gov.lk/page.asp?page=Education Accessed July 19, 2019.
} 
(Tripitaka), Sinhala, English and Mathematics. From the second year, students follow at least two optional subjects. The choice in many institutions includes Social Studies, General Science, Health, History, and more rarely, Hindi and Tamil. Students are expected to appear for a special state-run examination at the end of the five years. Upon successful completion of this examination, students can opt to enter a maha pirivena or a vidyayatana pirivena. The design of the mülika pirivena was thus meant to ensure that its graduates would be proficient in Buddhist scriptures and would have a basic knowledge of Buddhist texts as well as an understanding of the classical languages of the Indic World. The texts used for the teaching of required subjects include wellknown texts that have been traditionally used for the education of monks ${ }^{55}$ with the addition of more recently produced grammar texts and some selected novels. The provision of courses in English and Mathematics as well as some optional courses was meant to satisfy those who argued that in the context of the modern world, a basic training for monks should include secular knowledge.

In terms of knowledge of Buddhism, the mülika piriven provide detailed information on the life story of the Buddha and about his main disciples. Information is also provided on the four Buddhist Councils, which 'purified' Buddhist traditions, and the circumstances in which Buddhism emerged and grew in India. Monks learn about the proponents of Buddhism, including King Asoka (who supported the spread of Buddhism) and King Duṭgæmunu (who is acclaimed for fighting the Tamil King Eḷāra) ${ }^{56}$ as well as the monk and nun (Mahinda and Sangamitta) who brought Buddhism to Sri Lanka. Other persons about whom the monks learn include Valivita Saranankara who

\footnotetext{
${ }^{55}$ For example the Lōvædasan̆garāva, Gaṇadevihǣlla, Vadankavipota and Namāstaśatakaya, For information on the texts used in 18th century piriven see, Wijayasiriwardana, Vibhavi. Simhala Bhāṣādyayana Sampradāya hā Padya Grantha. Colombo: S. Godage, 2000.

${ }^{56}$ Other rulers about whom the monks learn in their third year in the mülika piriven, the year in which History becomes a defined subject in the curriculum include Devanampiyatissa 250-210 BC, Valagamba 103, 87-77 BC, Vasaba 67-111 AC, and Dhatusena 459-477 AC, all patrons of Buddhism. See, Piriven Adhyāpanaya Sẵdahā Itihāsaya: Tunvana Śrēniya. Colombo: Department of Educational Publications, 2016 (Reprinted 2017 and 2018), pp. 26-48.
} 
reintroduced Buddhist ordination to Sri Lanka in the mid-eighteenth century and Anagarika Dharmapala, who was a leader of the Buddhist revival in British colonial times. Monks also read jataka stories (accounts of previous lives of the Buddha and a selection of discourses about Buddhist doctrine. Monks at the mülika piriven are also introduced to increasingly complex texts on Buddhist doctrines as well as training in deportment. ${ }^{57}$

A maha pirivena has a wider curriculum including subjects such as Astrology, Ayurveda medicine, Philosophy, Sculpture, Economics, English, Civics and Handicraft. ${ }^{58}$ It was thus designed as a half-way house for those who wished to seek admission to a university. Indeed, an institution is classified as a maha pirivena only if it has at least 25 monks studying for prācina examinations or General Certificate of Education (Advanced Level). Since government grants to such schools depend on student enrollments, maha piriven have been happy to recruit lay students. ${ }^{59}$ Those who wish to attain proficiency in Sanskrit and receive the title of Rajjakiya Pandita need to attend one of the 65 vidyāyatana piriven in the country. Some of these vidyāyatana piriven have grown to be large and successful institutions providing educational opportunities to both monks and laymen. ${ }^{60}$ In all, by 2017 , there were 753 piriven. The 62,872 students studying in piriven in 2017 included 29,431 lay students. ${ }^{61}$ These figures do not include some vanavasi

\footnotetext{
${ }^{57}$ Samuels, Jeffrey. Attracting the Heart. pp. 67-71.

${ }^{58}$ In 2017 there were 221 maha piriven. See Table I.

${ }^{59}$ The proportion of lay students in piriven (46 to $47 \%$ of the total student body) has not changed substantially in the last 20 years. This percentage was 46.4 in 2015 , 46.9 in 2016 and 46.8 in 2017. See Table I.

${ }^{60}$ State grants to these institutions include the salary of the teachers and an annual subsidy. Piriven are also eligible to apply for small library grants.

${ }^{61}$ See Table I. It is worth noting that the number of students in piriven is a small fraction of the 4.17 million students in secular schools. Piriven have grown considerably from the 1996 level of 552 piriven with 43,228 students. By 2007 piriven enrolled 54,953 students as against 3.94 million in secular schools. They continued to grow swifter than total national student numbers in the next decade but piriven enrollments have remained fairly stable in recent years - 64,606 in 2015, 66,003 in 2016 and 62,872 in 2017. Piriven are also somewhat unevenly spread. See Table I. However, an analysis made two decades ago on the history
} 
(forest) institutes and independent piriven that do not seek state recognition.

The largely residential mülika piriven are the institutions designed to give monks a basic grounding in vinaya (discipline) and classical languages such as Pali and Sanskrit. They do provide a state supported system of schools that provide basic education (which encompasses Buddhist learning) for monks. There is some evidence that informal contact with the laity and senior monks does transmit some knowledge to them about the secular world. However, there are some deficiencies in the system. The questioning of the traditional Sinhala Buddhist version of Sri Lanka's past that has emerged from Sri Lankan universities has had limited percolation into the world of the piriven. Let us further interrogate the texts used in the teaching of history in mülika piriven.

The history texts used up to 2018 did have some strengths. The text used in the third year had provided a good concise survey of ancient civilizations in the Old World (Mesopotamia, Egypt, Mohendojaro, China) as well as a basic survey of Sri Lankan history. The text also specifically mentioned that King Vijayabāhu (1070-1110 AC) protected Hindu shrines and was popular among Hindus. ${ }^{62}$ Almost $25 \%$ of the text for the fourth year covered European history, thus providing monks with a view of the West. ${ }^{63}$

Nevertheless, there was little recognition of the contribution of minorities to the history of the country. In the 193-page history text for the $5^{\text {th }}$ year which recounted the History of Sri Lanka, only six pages

taught at the Sunday schools (daham pāsal) which provide religious instruction for over half a million Buddhist children revealed a version of history that painted the Tamils in an unfavorable light. See de Silva and Bartholameusz, The Sangha and the Reconciliation Process. p. 15.

${ }^{62}$ Piriven Adhyāpanaya San̆dahā Itihāsaya: Tunvana Śrēniya. p. 86. In the revised textbook for Grade 3, the coverage of ancient world civilizations continues. See pp. 90-146 in text.

https://drive.google.com/file/d/12y8tDBkwdhRGJlbX9iAheIGmDIX4kjvr/view?usp=s haring Accessed on July 19, 2019.

${ }^{63}$ Piriven Adhyāpanaya Să̌dahā Itihāsaya 4, Colombo: Department of Educational Publications, 1998 (14 ${ }^{\text {th }}$ Impression 2016) pp 36-58. 
dealt with the kingdom of Jaffna. Of these six pages, two pages related its conquest by the ruler of Kotte, two more pages described its conquest by the Portuguese and a great deal of space in the other two pages was devoted to a discussion on the lack of evidence of a Kingdom of Jaffna before the $14^{\text {th }}$ century. There was no mention of the contribution of the Muslim community to Sri Lanka. Therefore, for more than two decades these textbooks strengthened the view of Sri Lankan history as essentially that of the Sinhala Buddhists. Such a worldview had become accepted in the late $19^{\text {th }}$ and early $20^{\text {th }}$ centuries because it resonated with existing beliefs and gave a basis for anti-colonial and anti-Christian sentiments. It has persisted among Buddhist monks with minimal change after independence. This is unfortunate because one of the goals of education for all groups at all levels should be to address stereotypes, socio-cultural biases and beliefs as well as historical prejudices in ways that would increase tolerance.

In recent times, there has been an effort to update all textbooks (including history texts) used in mülika piriven. ${ }^{64}$ By 2019 revised history textbooks were introduced for Grades 3, 4 and 5 in virtually all mülika piriven. These texts are a major improvement on their predecessors, ${ }^{65}$ well-illustrated and with much better coverage of social economic and cultural history. In terms of attention to the historical contributions of ethnic and religious minorities too, the new texts have some positive features. ${ }^{66}$ Early in the texts for Grades 3 and 4 , the 'development of respect for other cultures' is listed as one of the purposes of history. ${ }^{67}$ There is specific mention of megalithic cultures existing before the arrival of migrants from North India. ${ }^{68}$ Pre-Buddhist belief

\footnotetext{
${ }^{64}$ This was under the direction of Professor Nabiriththankadawala Gnanarathana Thera, Director of Pirivena Education.

${ }^{65}$ The new textbooks often incorporate recent historical research and are generally free of factual errors. However, the textbook for Grade 4 states that the conquest of Constantinople by the Turks was a result of the Crusades (see, p.36) which is to take a very loose definition of 'Crusades.'

${ }^{66}$ See, http://www.edupub.gov.lk/Piriven_BooksDownload.php Accessed on July 19, 2019. The new textbooks also cover art and architecture and economic history better than their predecessors.

${ }^{67}$ See, p. 4 of the Grade 3 textbook and p. 2 of the Grade 4 textbook.

${ }^{68}$ See, Grade 3 text pp. 6-11 and Grade 4 text p. 31.
} 
systems including Jainism and Brahmanism are mentioned. ${ }^{69}$ The authors specifically mention that Elara, the $2^{\text {nd }}$ century Tamil king was just and was respected by his Sinhala successor, Dutugæmunu. ${ }^{70}$ While South Indian invasions are reported, the textbooks make it clear that Sri Lankan rulers also invaded South India, sought assistance from South Indian allies and made marriage alliances with royal families from South India. ${ }^{71}$ The textbook for Grade 5 has some brief references to the introduction of Catholic and Protestant faiths to the country as well as on the emergence of the community of Dutch Burghers. ${ }^{72}$

On the other hand, the attention to ethnic and religious minorities in these new history texts and thus, the background knowledge they provide for students in piriven (though an improvement on earlier textbooks), is still inadequate. The only mention of Muslims apart from a brief mention in page 17 of the Grade 3 textbook is on a half-page in the Grade 5 text describing the $19^{\text {th }}$ century Muslim Revival. ${ }^{73}$ Up Country Tamil Plantation workers are referenced only in a single sentence that states that they were incorporated into Sri Lankan society under British rule. ${ }^{74}$ The Kingdom of Jaffna gets one and a half pages in the 195-page Grade 4 textbook and another one and a half pages on its conquest by the Portuguese as well as two sentences on it's

\footnotetext{
${ }^{69}$ See, Grade 3 text p. 25 and Grade 4 p. 40. The tolerance of different religious beliefs in early history is also recorded on p. 55 of the Grade 4 text.

${ }^{70}$ See, Grade 3 text p. 15 and Grade 4 text pp. 57, 59.

${ }^{71}$ See, Grade 4 text pp. 63-63. 77, 92-93. 127, 133. However, Tamil settlers in the north of Sri Lanka are also depicted as being subversive of Sri Lankan interventions in South India. See, Grade 4 text pp.106-107.

${ }^{72}$ See pp. 40, 44, 47 and 61 in the Grade 5 textbook. The Grade 5 text also provides useful information on ancient civilizations (Greek, Roman, Ancient India) and on Buddhism in South East and East Asia in pre-modern times. See pp. 65-144 of the Grade 5 textbook.

${ }^{73}$ See p. 192 in the Grade 4 textbook.

${ }^{74}$ See p.194 in the Grade 4 textbook.
} 
conquest by Parakramabahu VI of Kotte. ${ }^{75}$ The vision of history taught today in piriven needs to become more inclusive. ${ }^{76}$

Also, the mülika piriven (and even the piriven at the next level, the maha piriven) do not provide a basic knowledge of other faiths, which, as we saw, was offered to students in pre-colonial times in the Vijayabāhu Pirivena. Moreover, the emphasis is on learning content rather than on critical analysis, the comprehension of theory rather than experimentation. ${ }^{77}$ Thus, the foundational knowledge that Buddhist monks receive in the mülika piriven is not necessarily the best basis for an understanding of a multi-cultural Sri Lanka.

In reality, only some monks at mülika piriven appear for the state administered final examination designed for these piriven. After completing four years at mülika piriven, many apply on their own to sit for the General Certificate of Education (Ordinary Level) Examination which is seen as an easier option as well as a means whereby one could advance to the General Certificate of Education (Advanced Level) Examination and to admission to a university. Akuretiye Amarawansa Thero claimed in 1996 that the prominence given to secular education, especially at the university level has led to a decline in the piriven. ${ }^{78}$ The movement to set up vanavasi (forest) and independent piriven has arisen because of the perception that mülika piriven have failed. The maha piriven, which provide education to Buddhist monks at the next level, do not provide compensations for the deficiencies in the mülika piriven. The

\footnotetext{
${ }^{75}$ See pp. 162-163 in the Grade 4 textbook and pages 29, 30, 43-44 in the text for Grade 5. In contrast, the rulers Dutugæmunu (161-137 BC) and Valagambā (89-77 $\mathrm{BC}$ ) who are depicted as saving the country from 'Dravida' invasions get six pages in the Grade 3 text (See, Grade 3 text pp. 33-39)

${ }^{76}$ Of course, inclusion is desirable component in the training of all preachers of all religions but given the influence of Buddhist monks among the majority in Sri Lanka, it is particularly important in piriven.

${ }^{77}$ For some recent efforts to improve the training of teachers in piriven see Newsletter at http://www.moe.gov.lk/pirivena/English/index.php Accessed on July $18,2019$.

${ }^{78}$ Amarawansa, Akuretiye. "Piriven Adhyāpanaya: Edā, Ada Saha Heța." Meegoda Sumanarathana Felicitation Volume. Maharagama: Meegoda Sumanarathana Upahara Kamituwa, 1996, p.77.
} 
maha piriven suffer from having to fulfill two different objectives. Their primary purpose was to provide an education for monks beyond the first level. However, they are also seen as institutions providing a second opportunity for many lay students who have dropped out of school but wish to be trained for state examinations. ${ }^{79}$ Indeed, as stated earlier, because the state grant for each pirivena is dependent on student enrollments, each institution has tried to increase its student numbers in competition with privately organized 'tutories' that also coach students for secular state examinations. Thus, many maha piriven seek to provide good instruction in Math and in theoretical elements of subjects such as Physics and Chemistry. English is one of the languages regularly taught in many maha piriven today.

While this curriculum provides opportunities for monks to pursue learning in the sciences and social sciences, and has enabled hundreds of monks to gain admission to Sri Lankan universities, it also conflicts with the need to provide a curriculum catering to the specific needs of monks. The vidyayatana piriven continue to produce some scholars of note in the field of Buddhist Studies, but even in those institutions, the window into the multicultural world of twentieth century Sri Lanka is limited.$^{80}$

To return to the argument that I started out with, I contend that the piriven which arose in the late $19^{\text {th }}$ century and developed in the $20^{\text {th }}$ are very different institutions from the educational institutions for monks in the $15^{\text {th }}$ and $16^{\text {th }}$ centuries. I argue that Orientalist and nationalist forces as well as colonial self-interest led to cooperation among monks, Buddhist leaders, the state and British officials to implant western style examinations ${ }^{81}$ and centralized control, all of

\footnotetext{
${ }^{79}$ The education of laymen was seen as an essential part of the role of piriven before the western system of schooling was introduced in colonial times. Therefore, in a sense, the maha piriven are returning to the role of piriven in pre-colonial times. ${ }^{80}$ See the curriculum in these piriven. More than half $(3,697$ of 6,782 in the year 2017) of teachers in piriven are lay persons.

${ }^{81}$ Incidentally, this also represented a further extension of state hegemony over society. As Michel Foucault points out “.. . in all the mechanisms of discipline, the examination is highly ritualized. In it are combined the ceremony of power and the form of the experiment, the deployment of force and the establishment of truth. At the heart of the procedures of discipline, it manifests the subjection of those who are
} 
which changed the system of education for monks. Buddhist educational institutions and the qualifications students obtained in them have come to be judged not on their own terms but on the basis of their equivalence to secular institutions and qualifications. This has inhibited the development of an education system specifically designed for the education of Buddhist monks.

However, there is an opportunity to go beyond the teaching of a particular interpretation of the past through archeology and history. The texts currently taught in the piriven lead to a particular Sinhala Buddhist worldview ${ }^{82}$ and an emphasis on a united, indeed a unitary Sri Lanka with Buddhism and Buddhists having a special place. Changing this emphasis is a challenging task because as the concept of being a Sinhala (Buddhist) ${ }^{83}$ and the linkage of this identity with the concept of Sri Lanka as a single unit is quite old ${ }^{84}$ and though it did receive a further impetus during the resistance to colonial rule. Nevertheless a beginning, however imperfect, at constructing a more inclusive history of Sri Lanka has been attempted in the new history textbooks for Grades 6 to 11 in secular schools introduced during the years 2015-2017. For example the history textbook for Grade 10 extols ethnic coexistence in Sri Lanka's precolonial history (pp. 60-61). That text also recognizes that central control of the Sri Lanka did not exist in early times and took

perceived as objects and the objectification of those who are subjected. The superimposition of the power relations and knowledge relations assumes in the examination all its visible brilliance." Foucault, Michel. Discipline and Punish: The Birth of the Prison. Vintage Books, 1979, p. 184.

${ }^{82}$ For examples of monks with these views see, Seneviratne, H. L. The Work of Kings. pp. 234-247 and Hettiarachchi, Nishantha, Role of Buddhist Monks in the Post-Conflict Reconciliation Process: The Case of Sri Lanka, Post-War Development and Rebuilding in Sri Lanka, ed. Upali Pannilage, Matara: University of Ruhuna, 2017, pp. 118-123.

${ }^{83}$ See Obeysekere, Gananath. "The Vicissitudes of the Sinhala Buddhist Identity through Time and Change." Collective Identities, Nationalisms and Protest in Modern Sri Lanka. ed. by Michael Roberts, Colombo: Marga Institute, 1979, pp. 279-313; Gunawardana, R. A. L. H. "The People of the Lion", and Dharmadasa, K. N. O. "The People of the Lion: Ethnic Identity, Ideology and Historical Revisionism in Sri Lanka." Ethnic Studies Report, X,1992, pp. 37-52.

${ }^{84}$ For example, sixteenth century rulers whom historians today describe as kings of Kandy or Kotte, described themselves as rulers of Lanka. 
time to evolve (pp. 37-38), thus contesting the idea of a continuously centralized and unitary Sri Lanka. It also details the existence of different faiths (pp. 56-58) and peoples (pp. 1-30) in ancient Sri Lanka. There is information about Christianity in Sri Lanka on pp. 76-77 of the Grade 8 text and pp. 54-56 of the Grade 9 text. Attention is drawn to the nineteenth century Muslim and Hindu revivals in the texts for Grades 9 and 11 . Such texts ${ }^{85}$ might provide a possible starting point for the revision of the history texts used in the piriven.

While changing the way history is taught in piriven has been a focus in this article, it is important to remember that there are other changes that could promote a more inclusive perspective among novice monks. ${ }^{86}$ Training, periodic seminars and refresher courses for the teachers in piriven are essential to realize the benefits of a reformed history curriculum. ${ }^{87}$ The current model of the authoritarian classroom is probably not the best way to inculcate respect for the rights of others. The emphasis within piriven on learning content rather than on critical analysis does not provide Buddhist monks with the most effective tools of learning. ${ }^{88} \mathrm{~A}$ reform of pirivena education that would provide

${ }^{85}$ Of course, the coverage of minority groups in these texts has significant gaps. Plantation workers barely get a mention (except on page 71 of the Grade 11 text). The Kingdom of Jaffna is mentioned only on pp. 60-61 of the text for Grade 3 and on pp. 102-103 and 131-132 in the text for Grade 10. Critical thinking takes a back seat as the Vijaya legend is presented as fact on pp. 33-34 of the Grade 6 text. See http://www.edupub.gov.lk/BooksDownload.php Accessed on July 19, 2019.

${ }^{86}$ For some ideas on what might be done through education in secular schools as well as in piriven see, de Silva, Chandra R. "The Role of Education in Ameliorating Political Violence in Sri Lanka," Cunningham, Jeremy and Suren Ladd. "The role of school curriculum in sustainable peace-building: The case of Sri Lanka." Research in Comparative and International Education, 13(4) December 2018, pp. 570-592 and Herath, Sreemali, Teachers as Transformative Intellectuals in Post-Conflict Reconciliation: A Study of Sri Lankan Language Teachers' Identities, Experiences and Perceptions, PhD Dissertation, University of Toronto, 2015.

${ }^{87}$ In 2017, the Department of Education classified 368 of piriven teachers (207 monks and 161 lay persons) as 'unapproved.' Their educational background could be the subject of a useful study.

${ }^{88}$ This particular aspect might take time to change because the emphasis on content at the expense of critical analysis is widespread in the whole school system in Sri Lanka. See, de Silva, Chandra R. "The Role of Education in Ameliorating Political 
Buddhist monks with a more relevant base of knowledge (including a basic knowledge of other religious philosophies) would prompt them to consider ethnic, sectarian and cultural diversity as an important part of the national heritage and further assist them to contribute to better relations among the different faith groups in Sri Lanka. ${ }^{89}$

Furthermore, as Gordon W. Allport pointed out more than half a century ago, changing what the young learn in school is not likely to be effective unless the culture of the community and its leadership also embrace new, more inclusive norms. As he put it "Suppose a child attends a lesson in intercultural education in the classroom. The chances are this lesson will be smothered by the more embracing norms of his family, gang or neighborhood. To change the child's attitudes, it would be necessary to alter the cultural equilibrium of these, to him, the more important groups. ... By involving the leaders, the policies, the rank and file, new norms are created and when this is accomplished it is found that individual attitudes tend to conform to the new social norm." 90

Violence.” pp. 124-125 and Jayawardene, Nanelle, How our Education System Fails to Address Ethno-linguistic Tensions, https://groundviews.org/2019/06/03/how-oureducation-system-fails-to-address-ethno-linguistic-tensions/

${ }^{89}$ The mission of the Piriven Education Branch of the Department of Education is to "creating a body of virtuous and disciplined priests who can support the wellbeing of Theravada monastic society and a body of citizens with the self-actualization of Sri Lankan identity." The vision is "While preserving the classical education tradition of Sri Lanka, to create a congregation of priest and lay citizens full of knowledge, attitudes and skills suitable for the contemporary requirements." http://www.moe.gov.lk/pirivena/English/index.php Accessed on July 19, 2019. ${ }^{90}$ See, Allport, Gordon W. The Nature of Prejudice, $25^{\text {th }}$ Anniversary Edition. Reading, Mass: Addison-Wesley Publishing Company, 1979, p. 40. To ameliorate this process, Mihiri Saritha Warnasuriya has suggested that the study of history in schools should include academic discussions of very recent events. However, continuous teacher training would be needed to increase the likelihood of positive outcomes from such discussions. See, Warnasuriya, Mihiri Saritha. "Examining The Value of Teaching Sensitive Matters In History: The Case of Post-War Sri Lanka." The International Journal of Historical Learning, Teaching and Research, 14 (2) Spring/Summer 2017, pp. 93-107. https://www.history.org.uk/secondary/resource/9194/examining-the-value-ofteaching-sensitive-matters Accessed on July 18, 2019. 
Repeated post-independence efforts in Sri Lanka to reform pirivena education have failed, leaving the monks with limited resources to attempt to deal with a rapidly changing world. In this context, the continued articulation of an inclusive world-view by a number of leading Buddhist monks in Sri Lanka is perhaps a testament to their ability to overcome a limited early training and the overall impact of the emphasis on metta (loving-kindness) towards all in Buddhist scripture. ${ }^{91}$

\footnotetext{
${ }^{91}$ See for example the Karañiya Metta Sutta.

https://thebuddhistcentre.com/features/urban-retreat-2013-blazing-sun/metta-suttapali-and-english-pdf Accessed on July 19, 2019.
} 
TABLE I: Piriven in 2017

\begin{tabular}{|c|c|c|c|c|c|c|c|c|c|c|}
\hline \multirow[t]{2}{*}{ District } & \multicolumn{4}{|c|}{ Piriven } & \multicolumn{3}{|c|}{ Students } & \multicolumn{3}{|c|}{ Teachers } \\
\hline & 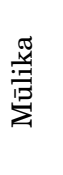 & $\sum_{\Sigma}^{\mathbb{\pi}}$ & 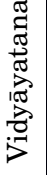 & $\begin{array}{l}\text { त्ञ⿰氵亏 } \\
\stackrel{0}{0}\end{array}$ & 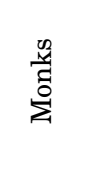 & 尝 & 氶 & 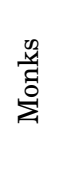 & త્త & 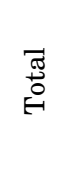 \\
\hline Colombo & 29 & 9 & 4 & 42 & 2,216 & 1,065 & 3,281 & 216 & 148 & 364 \\
\hline Gampaha & 35 & 21 & 2 & 58 & 2,573 & 2,758 & 5,331 & 304 & 261 & 565 \\
\hline Kalutara & 29 & 10 & 7 & 46 & 2,306 & 3,442 & 5,748 & 233 & 258 & 491 \\
\hline Kandy & 47 & 24 & 7 & 78 & 4,079 & 3,114 & 7,193 & 375 & 327 & 702 \\
\hline Matale & 11 & 9 & 1 & 21 & 993 & 549 & 1,542 & 104 & 71 & 175 \\
\hline Nuwara-Eliya & 6 & 3 & 1 & 10 & 637 & 234 & 871 & 53 & 35 & 88 \\
\hline Galle & 45 & 17 & 4 & 66 & 2,645 & 1,517 & 4,162 & 271 & 274 & 545 \\
\hline Matara & 49 & 11 & 6 & 66 & 2,552 & 2,689 & 5,241 & 253 & 371 & 624 \\
\hline Hambantota & 22 & 9 & 1 & 32 & 1,342 & 755 & 2,097 & 110 & 159 & 269 \\
\hline Vavuniya & 0 & 0 & 1 & 1 & 8 & 237 & 245 & 6 & 21 & 27 \\
\hline Mullaitivu & 1 & 0 & 0 & 1 & 30 & 14 & 44 & 2 & 4 & 6 \\
\hline Ampara & 13 & 4 & 0 & 17 & 699 & 223 & 922 & 60 & 57 & 117 \\
\hline Trincomalee & 4 & 1 & 1 & 6 & 252 & 227 & 479 & 24 & 19 & 43 \\
\hline Kurunegala & 42 & 35 & 7 & 84 & 3,617 & 3,921 & 7,578 & 349 & 439 & 788 \\
\hline Puttalam & 7 & 6 & 0 & 13 & 597 & 196 & 793 & 48 & 43 & 91 \\
\hline Anuradhapura & 24 & 15 & 3 & 42 & 1,913 & 1632 & 3,545 & 177 & 184 & 361 \\
\hline Polonnaruwa & 8 & 7 & 0 & 15 & 829 & 501 & 1,330 & 62 & 67 & 129 \\
\hline Badulla & 26 & 12 & 3 & 41 & 1,683 & 1,238 & 2,921 & 159 & 196 & 355 \\
\hline Moneragala & 16 & 4 & 3 & 23 & 917 & 1,091 & 2,008 & 83 & 130 & 213 \\
\hline Ratnapura & 35 & 7 & 7 & 49 & 1,527 & 2,114 & 3,641 & 208 & 229 & 437 \\
\hline Kegalle & 18 & 17 & 7 & 42 & 2,026 & 1,874 & 3,900 & 195 & 197 & 392 \\
\hline Sri Lanka & 467 & 221 & 65 & 753 & 33,441 & 29,431 & 62,872 & 3,292 & 3,697 & 6,782 \\
\hline
\end{tabular}

There are no piriven in the districts of Jaffna, Kilinochchi, Mannar and Batticaloa. Source: School Census 2017 (Provisional) Data Released on June 20, 2018. See http://www.statistics.gov.lk/page.asp?page=Education Accessed on July 15, 2019. 